\title{
Направленный нокаут гена вакуолярной инвертазы Pain-1 в Solanum tuberosum L.
}

Егорова А.А. ${ }^{1,2 *}$, Герасимова С.В. ${ }^{1,2}$, Коэппель И. ${ }^{3}$, Хамаз С. ${ }^{4}$, Хикель Ш. ${ }^{3}$, Хертиг К. ${ }^{3}$, Ибрагимова С.М. ${ }^{1}$, Сабоиев И.А. ${ }^{1}$, Нестеров М.А. ${ }^{1}$, Кумлен Й. ${ }^{3}$, Салина Е.А. ${ }^{1}$, Кочетов А.В. ${ }^{1,2}$

${ }^{1}$ Курчатовский геномный центр, Институт Цитологии и Генетики СоРАН, Новосибирск, Россия

${ }^{2}$ Новосибирский государственный университет, Новосибирск, Россия

${ }^{3}$ IPK, Gatersleben, Germany

${ }^{4}$ Erfurt Research Centre for Horticultural Crops, Erfurt, Germany

*e-mail: egorova@bionet.nsc.ru

Ключевые слова: картофель, генное редактирование, вакуолярная инвертаза

Картофель (Solanum tuberosum L.) является одной из самых важных мировых овощных культур. Для увеличения срока годности картофельных клубней их хранят в холоде. Одним из неприятных следствий этого хранения является накопление в клубнях восстанавливающих сахаров (глюкоза, лактоза, мальтоза и др.). Во время термической обработки эти сахара реагируют со свободными аминокислотами, что вызывает образование горьких темноокрашенных продуктов. Вакуолярная инвертаза расщепляет сахарозу на глюкозу и фруктозу. Показано, что подавление экспрессии гена вакуолярной инвертазы методом РНК-интерференции, а также выключение гена методом TALEN приводит к снижению уровня восстанавливающих сахаров [1]. Система редактирования с использованием РНК-направленной эндонуклеазы Cas9 является одной из самых точных и эффективных для редактирования генов растений. Поэтому мы решили выбрать данную систему для получения нокаута S. tuberosum по гену вакуолярной инвертазы Pain-1.

Мы выбрали три сайта-мишени и соответствующие им нРНК на кодирующей последовательности гена Pain-1. Для каждой нРНК была создана конструкция, несущая кодон-оптимизированный для Arabidopsis thaliana ген нуклеазы cas 9 под убиквитиновым промотором Petroselinum crispum и ген нРНК под промотором U6-26 A.thaliana. Активность нРНК в данных конструкциях была оценена методами восстановления активности гена-репортера путем направленного внесения мутаций [2] и на протопластах картофеля. Также была создана конструкция, несущая все три нРНК, ген нуклеазы cas 9 , ген-репортер $m$ Cherry для стабильной биобалистической трансформации растений картофеля и конструкция с тремя нРНК и геном нуклеазы на основе бинарного вектора p6i (DNA Cloning Service, Hamburg, Germany) для стабильной агробактериальной трансформации.

Исследование поддержано грантом РНФ (16-16-04073) и Курчатовским геномным центром ИЦиГ (075-15-2019-1662).

\section{Список литературы}

1.Clasen B.M. et al. Improving cold storage and processing traits in potato through targeted gene knockout. Plant Biotechnol Journal. 2016; 14: 169-176.

2.Budhagatapalli N. et al. A simple test for the cleavage activity of customized endonucleases in plants. Plant Methods. BioMed Central. 2016; 12(1):18. 